\title{
Explaining Howard's Success: Social Structure, Issue Agendas and Party Support, 1993-2004
}

\author{
MurRay GoOT And IAN Watson
}

Macquarie University

\begin{abstract}
In this paper we re-evaluate explanations, derived from the Australian Election Study surveys, for the Coalition's winning office in 1996 and holding it ever since. We show that, in occupational terms, electoral support for the major parties is less distinct than it was in the Hawke and Keating years. We document the shift to the Coalition, net of other factors, among older respondents, those with little education, and Catholics. And we show the shift to Labor among respondents from non-English speaking backgrounds. At the same time, we point to the failure of respondents on low or middle incomes to move in either direction. This leads us to an explanation for the Coalition's success grounded not so much in Labor's eroding blue-collar base but in terms of Howard's ability to construct a form of populist politics. We also demonstrate the significance of various issues, the part played by perceptions of the economy and the state of household finances, and the importance of voters' thinking that election outcomes matter. If we are right, not only are earlier analyses mistaken, but much of the political history of the period needs to be rewritten.
\end{abstract}

For a government elected (1996) and re-elected (1998, 2001, 2004) on four successive occasions, the Howard government's electoral performance has attracted less sustained attention from academic political scientists, and certainly less satisfactory explanations, than one might have hoped. The academic studies on each of these elections have carried only brief analyses of the Australian Election Study (AES) surveys (Bean and McAllister 1997; 2000; 2002; 2005). These, it is true, have been followed by more sophisticated analyses of the data in relation to the Coalition's victories in 1996 (Charnock 1997a; 1997b; McAllister 1997), 1998 (McAllister and Bean 2000), 2001 (McAllister 2003a) and 2004 (McAllister and Bean 2006). But most of these accounts - none of those by Bean and McAllister are compatible with their analyses in the election books - leave much to be desired as well. And there has been very little attempt to say something about the Howard years as a whole or to compare the Coalition's victories with Labor's victories from 1983 to 1993.

Murray Goot is Professor of Politics and International Relations and Ian Watson is Visiting Senior Research Fellow in the Department of Politics and International Relations at Macquarie University. The authors are grateful to Peter Brent, Andrew Leigh, Ian McAllister, Haydon Manning, John Warhurst and the Journal's referees for their comments on earlier drafts. 
Although the AES remains an indispensable source for the analysis of Australian electoral behaviour it is also a frustrating one. Accounts of the Coalition's success, in which Howard's appeal to the 'battlers' looms large (see, for example, Williams 1997, 64-5) or in which his attack on 'political correctness' is central (see, for example, McCrann 1996; Barnett with Goward 1997, 732), can be interrogated only in part through the AES surveys and then only with difficulty. What might be called the foundation myth of the Howard years, that Labor was thrown out of office because Paul Keating's 'big picture' ignored 'the battlers' and their concerns (see, for example, Barns 2003, 53), focuses on policy issues-a republic, reconciliation with Indigenous Australians and stronger relations with Asia-that the AES has ignored almost entirely. And the more recent wisdom that the government's hold on power hinges on Howard's appeal to 'aspirational' voters (see, for example, Hamilton and Denniss 2005, 137-8), also raises questions that the AES is ill-designed to answer.

Within these constraints, our paper uses the AES to address three questions either not previously asked or not persuasively answered. First, to what extent have the Coalition's victories depended if not on Howard's appeal to 'the battlers' then on his appeal to the 'blue-collar' vote? Second, what demographic variables other than occupation have helped drive voting behaviour since Howard came to office and what have been the most marked changes in the importance of these variables since the Hawke and Keating years? Third, to what extent do the political issues that the AES touches on-relations with Asia, taxation, interest rates, privatisation, health, education, terrorism and the war in Iraq-help explain changes in major party support, and to what extent have economic circumstances-changes in household finances or perceived changes in the economy at large, whether prospective or retrospective-accounted for the Coalition's success?

The paper shows that although 'blue-collar' respondents did shift to the Coalition in 1996, they were hardly a loyal band; at least in terms of their first preferences, they deserted in large numbers in 1998 not to return to the Coalition in anything like the same numbers until 2004. Other demographic factors, some of them not widely noted, made a difference as well. Comparing the Labor years for which there are AES data (1987-93) with the Howard years, we see a shift towards the Coalition among respondents aged over 60 years, among respondents aged 30-39 years (in comparison with those under 30 years of age), and among respondents who were Catholic (compared with respondents who were non-believers). Over the same period there was a shift towards Labor among respondents from non-English speaking backgrounds (compared with the Australian-born). We show, too, the issues that have mattered: defence, terrorism, taxation (as distinct from the Goods and Services Tax), and interest rates - all of which at one time or another worked for the Coalition; and health, education, the environment, and privatisation - all of which at one time or another worked for Labor. In addition, the government of the day benefited from respondents who sensed either that the economy had improved over the past 12 months or that it would improve over the next 12 months; whereas the opposition of the day benefited from respondents who regarded unemployment as an extremely important issue, thought the economy likely to go backwards over the next 12 months or thought their household's finances had gone backwards over the previous 12 months.

At the same time, our analysis casts doubt on a number of the factors often considered important to Howard's success. In 1996, it was not Keating's arrogance, his emphasis on Asia or the importance of immigration that helped the Coalition 
across the line. Nor were those respondents who voted for the Coalition especially worried about interest rates. In 2001, it was immigration rather than refugees that mattered, and terrorism rather than defence. And in 2004, respondents who attached great weight to education were not especially likely to have voted for the Coalition, Labor's caning over its promise to redistribute private school funds notwithstanding. Nor was Labor's promise to introduce Medicare Gold as damaging to its electoral appeal on health as is commonly supposed. And the Iraq War, far from being neutralised as an issue by Latham's pledge to bring the troops home by Christmas, appears to have cost the Coalition votes.

\section{Explanations Derived from the Australian Election Study}

Writing in the election books published since 1996, Bean and McAllister insist that when it comes to explaining the Coalition's success, social-structural variables count for virtually nothing. What matters instead are respondents' party identification, which is the single most powerful force; attitudes to the leaders (although which of the leadership items the modelling incorporates is never made clear); and issues respondents' were asked to rate for their importance during the campaign (Table 1). Of the issues they identify, only two (1998), three (2001) or four (1996, $2004)$ turn out to be statistically significant $(p<0.05)$. Taxation was significant in each of the four elections; health and Medicare, industrial relations and immigration

Table 1. Multivariate (OLS) analysis of the vote, Australian Election Surveys, Bean and McAllister, 1996-2004

\begin{tabular}{|c|c|c|c|c|}
\hline & 1996 & 1998 & 2001 & 2004 \\
\hline $\begin{array}{l}\text { Partisanship } \\
\text { Party identification }\end{array}$ & $0.48(0.46)$ & $0.49(0.47)$ & $0.53(0.52)$ & $0.47(0.44)$ \\
\hline $\begin{array}{l}\text { Leaders } \\
\text { Howard } \\
\text { Keating } \\
\text { Beazley } \\
\text { Latham } \\
\text { TV debates }\end{array}$ & $\begin{array}{c}0.14(0.09) \\
-0.18(-0.14)\end{array}$ & $\begin{array}{c}0.09(0.06) \\
-0.07(-0.04)\end{array}$ & $\begin{array}{c}0.16(0.12) \\
-0.16(-0.12)\end{array}$ & $\begin{array}{c}0.25(0.19) \\
-0.15(-0.10)\end{array}$ \\
\hline $\begin{array}{l}\text { Issues } \\
\text { Taxation } \\
\text { Health and Medicare } \\
\text { Industrial relations } \\
\text { Immigration/refugees } \\
\text { Education } \\
\text { Terrorism }\end{array}$ & $\begin{array}{l}0.13(0.09) \\
0.06(0.05) \\
0.07(0.05) \\
0.05(0.03)\end{array}$ & $\begin{array}{l}0.19(0.16) \\
0.07(0.05)\end{array}$ & $\begin{array}{l}0.22(0.15) \\
0.08(0.05) \\
0.05(0.04)\end{array}$ & $\begin{array}{l}0.09(0.07) \\
0.09(0.08)\end{array}$ \\
\hline $\begin{array}{l}\text { Social structure } \\
\quad \text { Age } \\
r^{2}\end{array}$ & $\begin{array}{l}1797 \\
0.75\end{array}$ & $\begin{array}{l}0.00(0.03) \\
1897 \\
0.73\end{array}$ & $\begin{array}{l}2010 \\
0.74\end{array}$ & $\begin{array}{l}1769 \\
0.75\end{array}$ \\
\hline
\end{tabular}

Note: Includes variables significant at $p<0.05$ or better; figures are for unstandardised (and standardised) coefficients.

Data weighted by vote.

Source: Australian Election Surveys: Bean and McAllister 1997, 205; Bean and McAllister 2000, 190;

Bean and McAllister 2002, 284; Bean and McAllister 2005, 331. 
mattered in 1996; health and Medicare in 1998; refugees and asylum seekers, and education in 2001; and health and Medicare and terrorism in 2004. Conversely, attitudes to unemployment, privatisation, the environment and defence were of no account in 1996; unemployment, privatisation, interest rates and education counted for nothing in 1998; unemployment, the GST, health, immigration and 'the war on terror' all failed to shift votes in 2001; and not only did unemployment, the environment, education, immigration, defence and the Iraq war not matter in 2004, interest rates did not matter either.

In a subsequent analysis of the 1996 data, McAllister came up with rather different figures. Although party identification, which accounted for $28 \%$ of the variance in the Coalition's vote, remained its most potent weapon, with 'party leaders' (16\%) also looming large (a correlation of 0.4 if one wants a direct comparison with the corresponding figures in Table 1), 'political issues' now accounted for $9 \%$ (a correlation of 0.3 ), 'attitudes to the economy' for $6 \%$ (a correlation in excess of 0.2 ), and 'social class' for $4 \%$ (a correlation of 0.2 ); for Labor the corresponding figures are only marginally different (McAllister 1997, 264 ). The differences between these numbers and those derived from the same data (Table 1) pass without mention.

The size of the variance Bean and McAllister claim to have explained should be treated with suspicion. The inclusion of party identification should always leave us 'wondering' whether 'party identification influences vote' or whether 'vote influence[s] party identification' (Curtice 2002, 162). The same is true of the correlation between support for party leaders and support for the parties they lead.

A more sophisticated analysis of the 1998 AES by McAllister and Bean (2000, 391-6), which focuses on the way issues drive the vote, omits party identification and leadership altogether. McAllister and Bean start with the thirteen issues respondents were asked to rank for their importance (i.e. 'most important', 'second most important ') to them and their families 'during the campaign'. For each issue they note what respondents said when asked 'whose policies-the Labor Party's or the Liberal-National Coalition's'-came 'closer' to their own views. And they look at what respondents had to say about macroeconomic issues (i.e. economic conditions in the past 12 months and likely conditions in the next 12 months); microeconomic conditions (i.e. what had happened to their household's well-being over the past 12 months and what was likely to happen to it in the next 12 months); and their fears about unemployment (i.e. personally and generally). Then, using data on the issues that emerged as the top four (GST, taxation, health and Medicare, and unemployment), on perceptions of macroeconomic and microeconomic conditions, and on economic insecurity, they run a series of regressions to explain, among other things, why those who voted Labor/LNP in 1996 switched to LNP/ Labor in 1998. A similar analysis by McAllister (2003a, 451-4) to explain defections between 1998 and 2001 focuses on the top seven issues but leaves out the macroeconomic issues, the microeconomic issues and data on economic insecurity. Turning to the defections in 2004 from the Coalition, from Labor to the Coalition and from Labor to the Greens, McAllister and Bean $(2006,617)$ take the top five issues, one macroeconomic and one microeconomic item, concerns about social services and interest rates, views about the war in Iraq, and ratings of Howard, Mark Latham (Opposition leader) and Bob Brown (leader of the Greens).

Although work of this kind represents a clear advance on the sort of analysis presented in the election books, it is not without its problems. First, the basis on which McAllister and Bean choose their issues is problematic. To go down the list and 
select the 'top' issues is to introduce criteria for making the cut that are fairly arbitrary. Second, when respondents were asked to say which party's position came closest to their own they were given only two alternatives: the Coalition's position and Labor's. Yet, with about 1 in 5 respondents having voted for a minor party, a choice of two hardly does the matter justice. Finally, a focus on defectors, admirable in principle, is hard to effect in practice. These are not panel data. They depend on the recall of respondents who may have little interest in politics and may have made lastminute decisions, not only at the immediately proceeding election but at the election before that, about how they were going to vote-hardly a reliable source

In our analysis we, too, use data from the AES. But the source has its limitations. None of the data were collected in 'real' time; all were collected some time after the event. Liberal voters are slightly over-represented (although we correct for this by weighting the data by electoral returns). More seriously, some of the items are less than satisfactory at measuring key social issues; respondents, for example, are asked about 'education' rather than 'educational standards', 'educational costs' or 'educational choice'. There are inconsistencies: questions on defence, but not in 1998; about interest rates, but not in 2001; and on mortgage repayments, but only in 1996. And for none of the elections are there data on the importance respondents attached to Aboriginal issues, a republic or any aspect of family policy.

Nonetheless, each of the surveys includes data on respondents' place of birth, gender, religion, age, education, jobs, employment sector (i.e. private or public), employer/employee status, and trade union membership. There are data on the importance respondents attached to certain issues-questions in a form that minimise but do not necessarily eliminate the effects of partisanship-and data on whether respondents cared which party won. And there are data on respondents' perceptions of their standard of living and on Australia's economic performance, both prospective and retrospective.

\section{Changes in the Occupational Pattern of the Vote}

One of the most remarkable things about changes in party support since the Labor years has been the changes at both ends of the occupational spectrum, with the Coalition losing support among managers (down from 67\% in 1987-93 to 61\% in 1996-2004) and gaining the support of blue-collar workers (up from 34\% to $39 \%$ ), deserting Labor not only for the Coalition but for minor parties (Table 2). However, Labor gained virtually none of the support the Coalition lost from the professional-managerial respondents (its support rose among managers but declined among professionals), its white-collar support declined (from $41 \%$ to $38 \%$ ) and its support among respondents in blue-collar jobs fell from 55\% to $45 \%$. Most of the Coalition's losses show up not as Labor gains but as gains to the minor parties; that is, the Australian Democrats, One Nation and the Greens. Most of Labor's losses, too, show up as gains for other parties; but the Coalition also gets a boost-especially from Labor's blue-collar base.

Although both sides lost support in their demographic heartlands, the Coalition's losses were much smaller than those of Labor's. And although the Coalition registered important gains that more than compensated for its losses, Labor made no compensating gains-not in its area of traditional strength, blue-collar workers; not among white-collar voters, wooed so effectively in the Whitlam years; not even among the professional middle class, to which Labor is said to have pitched its 
Table 2. Party support by occupation, Australian Election Studies, 1987-2004

\begin{tabular}{|c|c|c|c|c|c|c|c|c|c|c|c|c|}
\hline & Liberal- & $\begin{array}{r}\text {-Natio } \\
\text { (LNP }\end{array}$ & onal Par & & Austral & $\begin{array}{r}\text { lian La } \\
\text { (ALP }\end{array}$ & bor Par & & & linor pa & arties & \\
\hline & Managers & Profs & White & Blue & Managers & Profs & White & Blue & Managers & Profs & White & Blue \\
\hline$A L P$ & & & & & & & & & & & & \\
\hline 1987 & 71 & 48 & 47 & 33 & 26 & 41 & 43 & 59 & 3 & 10 & 11 & 8 \\
\hline 1990 & 64 & 41 & 43 & 36 & 23 & 35 & 38 & 48 & 14 & 24 & 20 & 17 \\
\hline 1993 & 67 & 39 & 47 & 33 & 26 & 40 & 42 & 58 & 8 & 21 & 12 & 9 \\
\hline 1987-1993 & 67 & 43 & 46 & 34 & 25 & 39 & 41 & 55 & 9 & 18 & 14 & 11 \\
\hline$L N P$ & & & & & & & & & & & & \\
\hline 1996 & 64 & 42 & 48 & 44 & 26 & 42 & 40 & 41 & 11 & 16 & 12 & 16 \\
\hline 1998 & 60 & 43 & 40 & 35 & 26 & 34 & 41 & 46 & 16 & 23 & 20 & 20 \\
\hline 2001 & 60 & 39 & 49 & 35 & 25 & 33 & 36 & 48 & 16 & 29 & 20 & 18 \\
\hline 2004 & 61 & 42 & 49 & 41 & 27 & 38 & 36 & 44 & 12 & 20 & 15 & 14 \\
\hline 1996-2004 & 61 & 42 & 46 & 39 & 26 & 37 & 38 & 45 & 15 & 22 & 18 & 19 \\
\hline
\end{tabular}

Note: Data weighted by Australian Electoral Commission returns.

Using ASCO1 (prior to 1998), white collar are defined as para-professionals, clerical and sales workers; blue collar are defined as tradespersons, machine operators and labourers. Using ASCO2 white collar are defined as associate professionals, advanced, intermediate and elementary clerical workers and sales workers; blue collar are defined as tradespersons, intermediate plant and machine operators and labourers.

Sources: Australian Election Studies: McAllister and Mughan (1987); McAllister et al. (1990); Jones et al. (1993); Jones, McAllister and Gow (1996); Bean, Gow and McAllister (1999, 2002); Bean et al. (2005).

policies with disregard to its blue-collar base. Among all these groups Labor's support went backwards.

The defections from both heartlands decreased the distinctiveness of each side's electoral support. In the period 1987-1993, the gap between the level of support for the Coalition parties among managerial respondents (67\%) and blue-collar respondents (34\%) was 33 percentage points; in 1996-2004, this gap (22 points) dropped by one-third. In 1987-1993, the gap between the level of support for Labor among managerial respondents $(25 \%)$ and blue-collar respondents $(55 \%)$ was 30 points; in 1996-2004, this gap (19 points) was almost halved. For both Labor and the Coalition the gradient in support, from one end of the occupational scale to the other, has become less steep under Howard than it was under Keating or Hawke.

When exactly did these changes occur? To answer this question we need to look at the data election by election. In the case of blue-collar workers, we need to look at tradespeople in particular. And we also need to look at the difference between blue-collar workers who were self-employed and blue-collar workers who were not.

\section{Managers}

Although support for the Coalition among managers has declined in the Howard years, this decline dates not from 1996 but from 1990. In 1987, 71\% of respondents who were managers said they had voted for either the Liberal or National Country Party; in 1990 through to 1996, the Coalition's vote among managers hovered at 
around two-thirds (64-67\%); since then it has dropped to $60 \%$ or $61 \%$. Labor, unlike the minor parties, gained little from this slide.

\section{Professionals}

Support for the Coalition among professionals has not declined-but it has fluctuated. It dipped in 1990 (41\%), when Labor, too, lost votes to the Democrats. The Coalition lost further ground in 1993 (39\%) when Labor recovered. But it gained-as did Labor_-in 1996 (42\%). In 1998, when support for the Coalition (43\%) held firm, Labor's support fell by 8 points, largely owing to the Greens (up 3 points) and One Nation (6 points). In 2001, the election that followed not only the attack on the United States but also the turning back of the Tampa, support for the Coalition among professionals declined by 4 percentage points - notwithstanding that the Coalition actually increased its share of the nationwide vote by $3.5 \%$ whereas support for the Greens jumped from $4 \%$ to $11 \%$. In 2004, when support for One Nation and the Democrats both collapsed, the Coalition's vote among professionals rose by 3 points and Labor's by 5 points.

\section{White-collar workers}

If there was a swing to the Coalition in 1996 among white-collar respondents, it was barely noticeable when almost half (48\% compared to $47 \%$ in 1993) said they had voted either Liberal or National. However, among white-collar respondents the 1998 election and the rise of One Nation saw a big swing away from the Coalition. The only swing towards the Coalition of any size - a swing that lifted its share of the vote from $40 \%$ (1998) to $49 \%$ - came in 2001. This returned it to roughly where it had been in 1996.

For Labor, on the other hand, 2001 marked a new low with white-collar respondents shifting to the Democrats and the Greens; in 1998, $41 \%$ of white-collar respondents said they had voted Labor, but in 2001 no more than $36 \%$ said they had done so. Worse, in 2004, when the combined support for the Democrats and Greens returned to its 1998 level, support for Labor (36\%) remained unchanged.

\section{Blue-collar workers}

The jump in the Coalition's support among blue-collar respondents dates precisely from 1996. In the Liberal Party's 1996 exit poll, conducted across the '52 most marginal seats', $47.5 \%$ of blue-collar respondents, according to Robb (1996), voted for the Coalition; compared with a vote of $43 \%$ in 1993, this represented a gain of almost 5 percentage points.

The AES data, derived from respondents in safe seats as well as those in the marginal seats, tell a story that is less dramatic in terms of the size of the Coalition's bluecollar vote but more dramatic in terms of the size of the blue-collar swing. In the AES, $44 \%$ of blue-collar respondents said they had voted for the Coalition; this compares with only $33 \%$ in 1993 . For the first time, more blue-collar workers said they had voted for the Coalition than said they had voted for Labor.

Since 1996, the time when Labor could command the majority of the blue-collar vote, or outpoll the Coalition by nearly two votes to one, Labor has receded into an increasingly distant past. As Table 2 shows, not since 1993, after Dr Hewson 
threatened to introduce a GST and dismantle Medicare, has Labor won an absolute majority of blue-collar respondents. In 1990, as it chased the environmental vote, its support among blue-collar respondents dropped to less than half (48\%). In 1996, its support fell even lower (41\%).

In 1998, contrary to expectations that Hanson would split the Labor vote (see, for example, Jackman 1998), more blue-collar respondents switched to Labor than moved away; Labor's share of blue-collar respondents rose to $46 \%$ ( $c f$. $48 \%$ in 2001). It was the Coalition's share, not Labor's, that Hanson hit (Goot and Watson 2001); Liberal-National Party support fell to just over one-third (35\%) and remained at that level in 2001, notwithstanding that One Nation's electoral support had passed its peak. Not until 2004 did the Coalition's vote recover (up by 6 percentage points). Conversely, Labor's share of blue-collar respondents declined-its loss of support among blue-collar respondents apparently bigger than its loss of support in the electorate as a whole. For the first time since 1996, blue-collar respondents were divided almost evenly between the Coalition (41\%) and Labor (44\%).

Tradespeople What can we say about those blue-collar respondents who worked in a trade? Basing his analysis on election returns and the 2001 Census, Black (2006) argues that 'tradespersons, the former backbone of the ALP and ACTU leadership, are now evenly split, swinging in 2001 and 2004 from Labor to Liberal'. The AES data confirm part of this story but not all of it. Tradespeople did swing to the Coalition in 2001, and in 2004 were 'evenly split' (42 : 42). But they were evenly divided (41:41) in 2001. Compared to 1996, when it turned a $36: 52$ deficit into a 46 : 40 lead, the Coalition's grip appears to have weakened. This is largely because of the damage inflicted in 1998 by Hanson, when the Coalition's support, and Labor's, split 34 : 45. And although 1996 is an election from which Labor has never recovered, its losses were not without precedent; in 1990, tradespeople were also evenly split, $40: 38$.

Self-employed Increasingly, those who work in blue-collars jobs are self-employed. Among blue-collar respondents, the self-employed averaged 19\% between 1987 and 1993. Since then, among AES respondents, it has grown to $25 \%$.

Did self-employment make a difference? In 1996 the swing to Howard appears to have been more marked among blue-collar respondents who were self-employed (a gain of 11 percentage points) than among those who were not self-employed (a gain of 7 points); nonetheless, the shift from Labor was no more marked among the selfemployed (a fall of 17 points) than it was among those who were not self-employed (a loss of 15 points). In 1998, the shift away from the Coalition among blue-collar respondents-partly to Labor, partly to Hanson-was almost entirely due to the massive desertion of those who were self-employed (down by 26 points compared to a drop of just 2 points among those who were not self-employed). In 2004, again, it was blue-collar respondents who were self-employed who swelled the Coalition's ranks; support for the Coalition among these respondents jumped by 19 points whereas among those not self-employed it rose by just 2 points. Nonetheless, in 2004 support for the Coalition among blue-collar respondents who were selfemployed (59\%) was substantially lower than it had been in 1996 (69\%); support for Labor was much higher (32\% compared with 19\%). Among blue-collar workers not self-employed, the Coalition's share of the vote in 2004 (36\%) was about the same as it had been in 1996 (35\%). 
In short, if Keating lost a large swag of the blue-collar self-employed to Howard in 1996, Howard has had considerable difficulty holding them; in 1998 and 2001, he lost all of them-and a lot more besides. Howard has been much more successful holding on to blue-collar workers who are not self-employed.

\section{Labor and Coalition Victories Compared: 1987-93 to 1996-2004}

If we want to know which of the many characteristics associated with employment actually shaped the choices of our respondents, we need to move from bivariate to multivariate analysis. This also allows us to plug in a range of other variables: characteristics of the respondents, like their age, gender, place of birth and religion; and their position on a whole raft of issues.

We start by aggregating the AES data from 1987 to 1993, and from 1996 to 2004. We then run two multinomial logit models to see if there are any notable trends in the socio-structural basis of support for the parties. In the first set of results, which is presented as relative risk ratios and is similar to odds ratios (Table 3), the independent variables are gender, age, occupation, private sector employment, and trade union membership, place of birth, religion and marital status. The coefficients indicate the odds (compared to the reference group) of those with a given characteristic voting for the Coalition rather than for Labor, or voting for the minor parties rather than for Labor.

In the pre-Howard period the odds of a male voting for the Coalition rather than for Labor was 0.86 (compared with a woman), whereas in the Howard years the odds were 0.93 . If the odds had shifted to 1.00 this would have meant that men were just as likely as women, other things being equal, to have voted for the Howard government. The modelling suggests that although the Coalition under Howard may have improved its performance among men relative to its performance among women, as Robb $(1996 ; 1997,41)$ observed, the improvement is not statistically significant net of other factors.

To find in which category the Coalition clearly improved its position or to see whether its position slipped we have to look elsewhere. First, to the category of respondents aged 30-39 years, in which the Coalition reduced its disadvantage (compared with those aged 18-29 years), and to the category of respondents aged 60 plus, in which it increased its advantage substantially. If the gains among the 30-39 year-old group are surprising, the gains among older voters are not; a study of the Howard decade, undertaken by the National Centre for Social and Economic Modelling, shows 'the nation's most favoured voters' have been 'part-pensioners with private incomes of $\$ 250$ to $\$ 500$ a week' (Harding 2006). Second, we have to look to Catholics (compared to non-believers), for whom the Coalition reduced its disadvantage as well. Third, we have to look at the category comprising those voters with lower levels of formal education, in which the Coalition also reduced its earlier disadvantage.

Although the Prime Minister also targeted 'low- and middle-income families' (Megalogenis 2006, 262), the odds of low-income earners or middle-income earners (compared to high income earners) voting for the Coalition, which was never high, were no higher in 2004 than they had been in 1993 (Table A1). As for the blue-collar vote, there was no statistically significant change between the two periods, suggesting how the bivariate results can mislead. 
Table 3. Multinomial logit model of voting, Australian Election Studies, 1987-2004 (relative risk ratios)

\begin{tabular}{|c|c|c|c|}
\hline LNP vs ALP & 1987-93 & 1996-204 & Change $^{\#}$ \\
\hline Male & $0.84^{*}$ & 0.90 & \\
\hline $30-39$ years & $0.76^{* *}$ & 0.95 & * \\
\hline $40-49$ years & 1.11 & 1.07 & \\
\hline $50-59$ years & $1.31^{*}$ & $1.35^{* *}$ & \\
\hline $60+$ years & 1.10 & $1.57^{* * *}$ & ** \\
\hline No post-school qualifications & $0.74^{* * *}$ & 0.91 & $\dagger$ \\
\hline Trade qualifications & 0.86 & 1.12 & \\
\hline Tertiary educated & 0.86 & 0.85 & \\
\hline Manager & $1.76^{* * *}$ & $1.55^{* * *}$ & \\
\hline Professional & 1.06 & $1.20^{*}$ & \\
\hline White collar & 1.05 & 0.98 & \\
\hline Blue collar & $0.61^{* * *}$ & $0.68^{* * * *}$ & \\
\hline Private sector & $1.26^{* *}$ & $1.41^{* * *}$ & \\
\hline Employee & $0.48^{* * *}$ & $0.53^{* * *}$ & \\
\hline Trade union member & $0.61^{* * *}$ & $0.52^{* * *}$ & \\
\hline ESB migrant & 0.86 & $0.80^{*}$ & \\
\hline NESB migrant & 0.90 & $0.61^{* * *}$ & $* * *$ \\
\hline Catholic & $0.75^{* * *}$ & 0.93 & $*$ \\
\hline $\mathrm{C}$ of $\mathrm{E}$ & 1.13 & $1.29^{* * *}$ & \\
\hline Married & $1.21^{* *}$ & $1.19^{*}$ & \\
\hline Constant & $2.48^{* * *}$ & $1.59^{* *}$ & \\
\hline No. observations & 5485 & 5857 & \\
\hline Log likelihood & -5048.48 & -5723.88 & \\
\hline Pseudo $r^{2}$ & 0.07 & 0.05 & \\
\hline
\end{tabular}

Note: Data weighted by Australian Electoral Commission returns.

Coefficients are shown in exponential form; that is, as relative risk ratios (similar to odds ratios).

Omitted dummy categories (reference groups): age: 18-29 years; occupation: 'other' (i.e. nonworking), although the comparison is against the grand mean rather than against the omitted category; employment sector: public; place of birth: Australian-born; religion: other, including non-believers. ${ }^{*} p<0.05 ;{ }^{* *} p<0.01 ;{ }^{* * *} p<0.001 ;{ }^{\dagger}$ significant at 0.07 .

\#Based on cross-model $t$-tests using Stata's suest command.

But if the Coalition improved its position, it lost ground as well. Its slight disadvantage in the pre-Howard years among non-English-speaking-background (NESB) migrants (compared to the Australian-born) grew with Howard in office. Multiculturalism was something regarded with suspicion, if not hostility, by the Howard government. It may be that in 2001 'Liberal Party polling showed a large majority of NESB Australians supporting the stand against asylum seekers' (Jupp $2002,264)$, but there is no evidence here of their shifting their votes.

\section{Hewson's Defeat and Howard's Victories: 1993 to 2004}

To see what factors drove the vote when Howard came to office in 1996, what factors drove the vote in 1993, and what factors have driven the vote since, we need to model a wider range of variables and we need to look at each election in turn (see Appendix Table A2).

There are four broad categories of independent variables: demographic variables (now included as controls); variables that touch on campaign issues (respondents' 
ratings of the importance of each of a dozen or so issues); variables that measure respondents' household finances, looking back 12 months and forward 12 months, and the way they think the broader economy has changed over the past 12 months and might be expected to change in the coming 12 months; a variable designed to assess whether respondents changed their vote from the previous election; and a variable to measure whether they cared a great deal about the outcome of the election.

For ease of exposition, we present our key findings in the following tables as changes in predicted probabilities of voting for each of the parties. For example, Table 4 shows that, for an 'average' respondent in 1993 who rated health issues 'extremely important', the predicted probability of voting for the LNP was 12 percentage points lower than for an 'average' respondent who did not regard health issues as 'extremely important'. Note that these percentages are changes in the predicted probabilities for the 'average' respondent, and not changes in the party's share of the sample's vote. Although a particular attitude might have a considerable impact on the predicted probability, the attitude itself might not be held widely. To help the reader keep this in mind, we also show the proportion of respondents who shared that particular attitude.

\section{3}

It is often assumed that the GST rescued Labor in 1993. But there is a good deal more to the story than this. As Table 4 shows, for the average respondent for whom the GST was 'extremely important' - and more than half the respondents fell into this category - the predicted probability of voting Labor rose by 14 percentage points compared to the average respondent for whom the GST was not extremely important. However, this was not the only issue that mattered. For the average respondent for whom health was 'extremely important', whereby two-thirds of the respondents fell into this category, the predicted probability of voting Labor rose by $11 \%$; for the average respondent for whom education was 'extremely important'-and almost half the respondents fell into this category-the predicted probability of voting Labor rose by $11 \%$; and for the average respondent for whom the environment was 'extremely important' - and more than one-third of the respondents fell into this category - the predicted probability of voting Labor rose by 9 percentage points (although minor parties benefited equally at the Coalition's expense).

As one might expect, adverse economic impacts worked in the Opposition's favour. Thus, the average respondent for whom unemployment was 'extremely important' - and two-thirds of the sample fitted this category-was 11 percentage points more likely to have voted for the Coalition. And, as Table 5 shows, the average respondent who thought 'the general economic situation in Australia as a whole' was likely to be worse 'in 12 months' time'-two respondents out of five-was more likely, by 44 percentage points, to have voted for the Coalition. There were other, smaller, impacts as well. Thus, although the average respondent who thought the 'general economic situation' worse than it had been 12 months ago was more likely (by 27 percentage points) to vote for the Coalition, the proportion that felt that way was quite small (15\%). And although the average respondent who thought 'the financial situation' of their household was worse now than it had been 12 months ago was more likely (by 12 percentage points) to have voted for the Coalition, the numbers in this category were equally small. However, the Coalition did not benefit from those respondents, comprising nearly half the sample, who felt their households had gone backwards over the previous 12 months. 


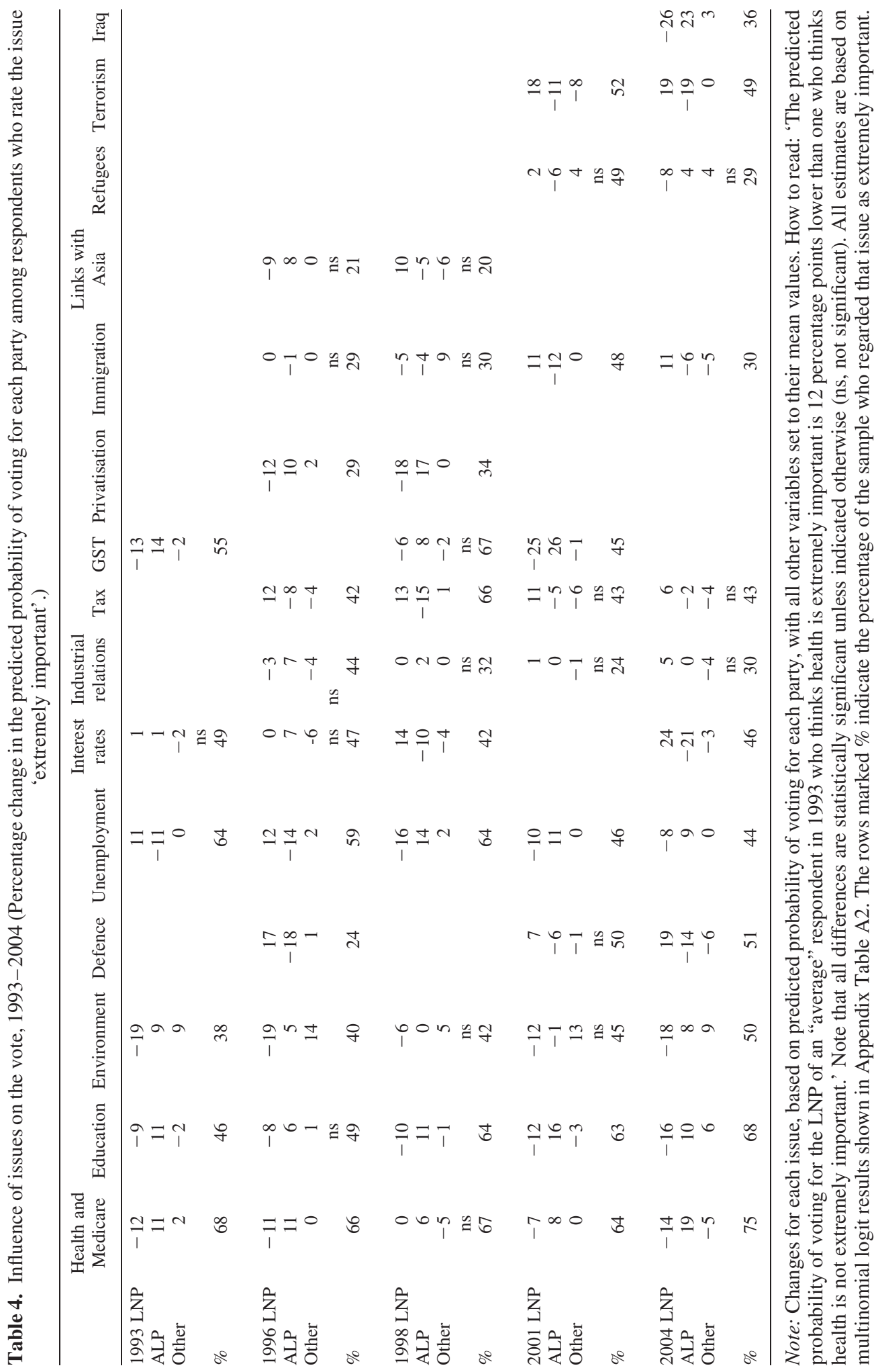




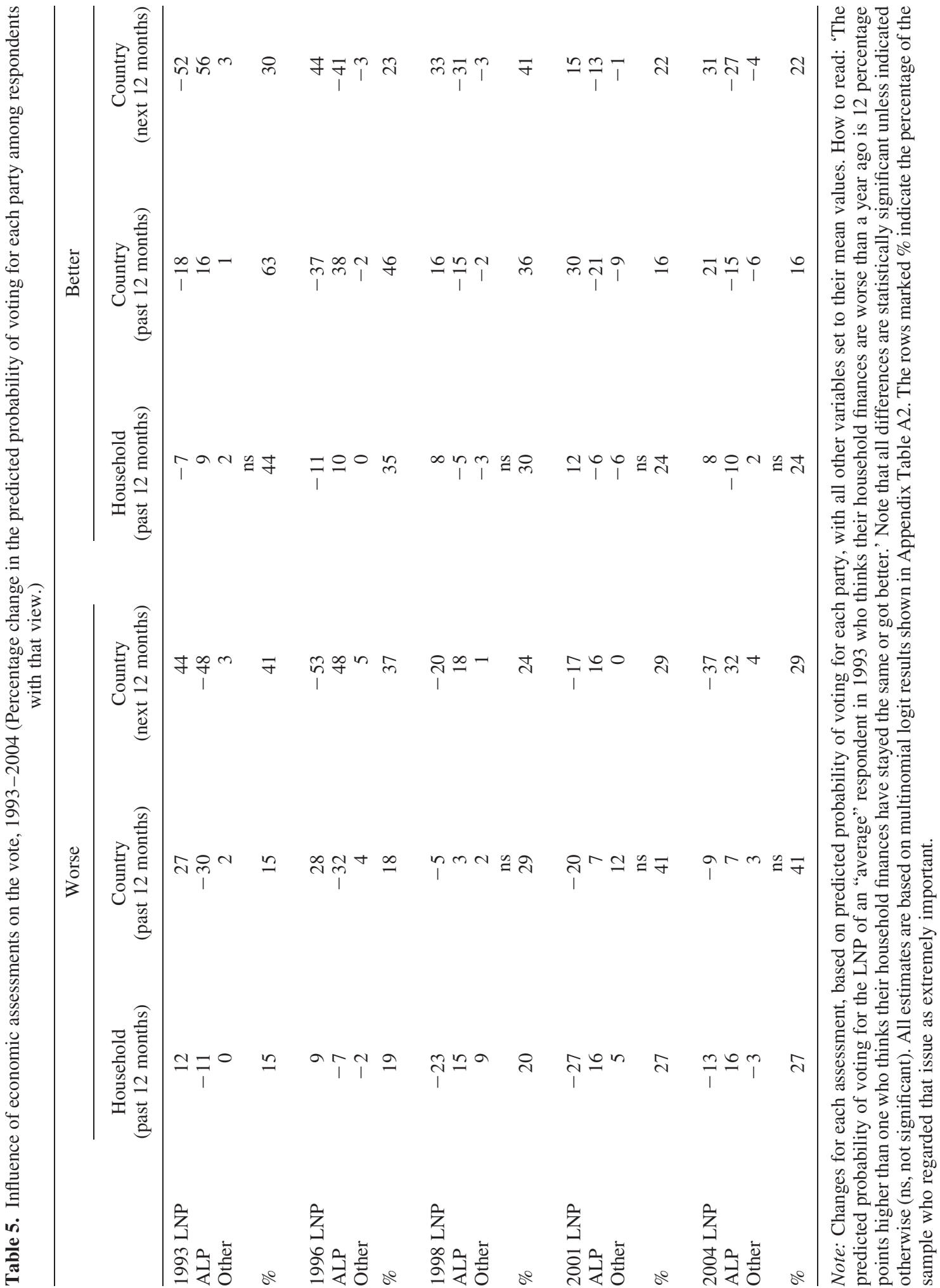


If the Coalition picked up some of the economic losers in 1993, Labor benefited from some of the economic winners. For the average respondent who thought things would be better in 12 months' time (and they constituted nearly one-third of the sample), the probability of voting Labor rose by 56 percentage points. And the average respondent who thought the 'general economic situation' was better than it had been 12 months ago was also more likely (by 16 points) to have voted Labor; no fewer than $63 \%$ shared this view. However, interest rates, mentioned by half the respondents as 'extremely important', did not shift votes either way (Table 4).

\section{6}

Even in defeat, Labor still held the advantage on health and, more narrowly, on the environment (with most of the Coalition losses benefiting the minor parties rather than going directly to Labor). And, despite the best efforts of the Coalition to neutralise the issue (Goot 1999), Labor also enjoyed a modest advantage on the issue of privatisation. However, Labor no longer held a statistically significant advantage on education.

The Coalition held on to its advantage on unemployment, was preferred by those ( 2 in 5) for whom taxation was 'extremely important' (the GST item was dropped for this election so we can't say whether its impact lingered), and enjoyed a clear advantage on defence (rated 'extremely important' by one-quarter of the sample). Again, interest rates counted for nought in influencing the vote, as did industrial relations, although both were rated 'extremely important' by nearly half of those interviewed. Immigration and links with Asia, each rated 'extremely important' by about onequarter of the sample, also left no mark.

On the health of the economy as a whole, and on the health of household budgets in particular, the pattern of advantage and disadvantage was much as it had been in 1993. However, although Labor increased its advantage (38 compared to 16 points) among those who thought the 'general economic situation' better than it had been 12 months ago, the proportion who felt the economic situation was better than it had been 12 months ago was lower (46\%, down from 63\%); the proportion who felt the 'financial situation' of their household was better than it had been 12 months ago was also lower (35\%, down from 44\%). Although the Coalition benefited from those who thought 'the general economic situation in Australia' would be better in 12 months' time (an advantage of 44 percentage points), its advantage was not as great as Labor's in 1993 and the proportion (23\%) who shared this view of the economic outlook was not as great as it was in $1993(30 \%){ }^{1}$

What does stand out (although not shown as predicted probabilities) is the impact of 'concern' about the outcome of the poll. For those who 'cared a good deal which party won the Federal election', or who voted one way in 2001 and another in 2004, the impacts were large. Among these respondents, the odds of voting for the Coalition over the ALP were about 3 to 1 (see Appendix Table A2).

And notwithstanding the view among commentators (see, for example, Brown and Stewart 1996) that Keating's arrogance was a key factor in the Coalition's win-a view we felt we had to test, our scruples about leadership items notwithstandingthis variable shows no statistically significant relationship with the vote.

\footnotetext{
${ }^{1}$ Note that the reversal of the signs in Table 5 between 1993 and the other years reflects the change in government after 1996. The unusual pattern in 1996 reflects the fact that the past 12 months was under Labor whereas the coming 12 months were under the Coalition.
} 
If the 1998 election was a 'referendum' on the GST, it appears to have ended in a tie; as a vote-shifter it was statistically insignificant. Nor were Labor's advantage on health and the Coalition's disadvantage on the environment statistically significant. However, education (now 'extremely important' to two-thirds of the respondents) remained a Coalition weakness; unemployment, a negative for Labor in 1996, was now a problem for the Coalition; and privatisation remained a Coalition negative as well (although only one-third rated it as 'extremely important'). The two issues raised in the AES on which the Coalition enjoyed an advantage were interest rates (for the first time) and, more importantly (because two-thirds rated it 'extremely important'), taxation - an issue, unaffected apparently by the GST, on which there had been little change since 1996. Again, industrial relations, immigration and links with Asia left no mark.

The economy was now an advantage to the Coalition in a way that it had not been in 1996 when many more respondents thought economic conditions had improved in the past 12 months (46\%) than thought they had gone backwards (18\%). In 1998, on the Coalition's watch, the difference in the proportions who thought the economy had improved and who thought it had deteriorated was small; but the Coalition enjoyed a clear advantage among those who thought things had improved and suffered no statistically significant disadvantage among those who thought things had gone backwards. Again, whereas more respondents after the 1996 election thought the economy would do worse (37\%) in the next 12 months rather than better (23\%), after the 1998 election more respondents expected it to do better (41\%) rather than worse $(24 \%)$.

Those (20\%) who felt their household finances had gone backwards, like those who felt the economy had gone backwards, moved to Labor and the minor parties. More respondents (30\%) felt that their household's finances had improved over the past 12 months, but this did not affect the probability of their voting for the Coalition.

\section{1}

The 2001 election might have been characterised as the 'Tampa election' but, on the evidence of the AES, it was not; although half the sample (49\%) thought refugees an 'extremely important' issue, the probability that those who thought this way voted for the Coalition was not significantly greater than the probability that they had voted for Labor. What did work for the Coalition was the related issue of immigration; having not worked for the Coalition in 1996 or 1998, the issue of immigration-'We will decide who comes to this country and the circumstances in which they come', as the Prime Minister put it-increased the predicted probability of voting for the Coalition by 11 percentage points among those respondents (48\%) for whom it was 'extremely important'. Again, although defence did not work for the Coalition (despite being nominated as 'extremely important' by 50\%), the related issue of terrorism did; identified as 'extremely important' by half (52\%) of the respondents, terrorism increased the predicted probability of voting for the Coalition by 18 percentage points, taking support not only from Labor but also from the minor parties. In short, the main issues were not refugees and terrorism but immigration and terrorism. Nonetheless, on neither issue was the Coalition's advantage as great as many commentators imagined. 
On domestic issues, the news for the ALP was generally good. It regained the edge on health, retained an even stronger edge on education and on unemployment, and on the GST-despite the 'limited' nature of its 'rollback' - it enjoyed a remarkable advantage (26 percentage points) among those ( $45 \%$ of the sample) who rated the issue 'extremely important'. On the more general issue of taxation, the Coalition also made no headway. One area in which Labor lacked strength was the environment. And for the third time in succession, industrial relations left no mark.

On the economy and on household finances, the news for the Coalition was much better as, for the most part, rosy assessments outnumbered gloomy ones. Those who thought things had improved in the past 12 months $(41 \%)$ or would improve in the next 12 months (37\%) were more likely to have voted for the Coalition. Those who thought things had got worse in the past 12 months (only 25\%) or would get worse in the next 12 months $(42 \%)$ were more likely to have voted Labor; but this was a relatively small group and Labor's advantage ( 7 percentage points) was relatively narrow. Similarly, those who thought their household finances had improved $(41 \%)$ were more likely to have voted for the Coalition than for Labor. And although those who thought their household finances had gone backwards $(21 \%)$ were more likely to have voted Labor, their number was only half as great as those who thought their household circumstances had improved.

Nor should we overlook the advantage the Coalition enjoyed among respondents for whom it really mattered which party won. Although the advantage was not as great as it was in 1996, it was significant nonetheless (see Appendix Table A2).

\section{4}

There seems little doubt that interest rates won the 2004 election for the Coalition. Among respondents who rated interest rates as extremely important (46\% of the sample), the probability of voting for the Coalition was 24 percentage points higher than the probability of voting for the ALP. Those who thought the economy was better than it had been 12 months earlier favoured the Coalition by a similar margin; but they only accounted for $16 \%$ of the sample. Those who thought the country would be better off in 12 months' time favoured the Coalition by a greater margin, but those who thought the country would be worse off in 12 months counterbalanced them. And, whereas the Coalition gained no advantage from those who thought their household's position had improved over the past 12 months, it lost votes among those who thought their households had gone backwards.

Interest rates apart, and allowing for the fact that the AES did not ask about forests' policy, domestic issues appear to have not served the Coalition well. On health, education and the environment-issues rated 'extremely important' by upwards of half those interviewed-Labor enjoyed a clear advantage. Labor's strong showing on health, which was rated 'extremely important' by an exceptionally high $75 \%$, was not negated by the controversy generated by its Medicare Gold policy; nor was its lead on education overtaken by its schools' funding policy. On unemployment, Labor was also ahead. Industrial relations and taxation made no difference either way.

But for the Coalition the Iraq war proved as big a liability as any; among those who thought the issue 'extremely important' (36\% of the sample) the chances of voting for the Coalition declined by 26 percentage points, with the probability of voting for Labor increasing by almost as much. However, the Coalition's losses over the war in Iraq were more than offset by its gains from defence and the issue of terrorism. On defence, which 
was rated 'extremely important' by half $(51 \%)$, the probability of voting for the Coalition increased by 19 points; on terrorism, which was rated 'extremely important' by $49 \%$, the probability of voting for the Coalition also rose by 19 points. And, although no advantage accrued to it through refugees, the issue of immigration again gave the Coalition a boost.

\section{Conclusion}

A number of contemporary changes in the workforce and the labour market have worked against Labor: a relative if not absolute decline in blue-collar jobs, a shift from public to private sector employment, a low and declining level of unionisation, and the rise in the incidence of self-employment. These changes do not spell the end of Labor's chances of forming a government. Whitlam's remaking of the ALP in the face of the growing importance of white-collar work and professional jobs, evidence that self-employed workers in blue-collar jobs; that is, 'aspirationals', are not especially likely to vote for the Coalition (Goot and Watson 2007), and the success of Hawke and Keating - not to mention Labor's complete dominance at the state level-show that changes of this kind do not necessarily consign the ALP to the political also-rans. But Labor does face a challenge.

Clearly, the Coalition's occupational base and that of Labor's are increasingly similar. Although Labor's pursuit of professional workers may not have delivered it many votes, its loss of support among blue-collar workers and, to a lesser extent, among white-collar workers has made it more dependent than ever on the professional-managerial class. Between 1987 and 1993, fewer than 1 in 5 (18\%) of those who participated in the AES and who voted Labor were either professionals or managers; since 1996, with the notable exception of $1998,25 \%$ of its vote, on average, have come from these groups. ${ }^{2}$ What is equally remarkable is that the Coalition has become increasingly dependent not on blue-collar workers-it has become less dependent on them-but on the white-collar vote. This is largely a consequence of its loss of professional-managerial support. Having hit a high of $28 \%$ in the 1996 AES, the Coalition's dependence on blue-collar workers has declined; in 2004 it accounted for just $18 \%$ of its vote. By contrast, its dependence on the white-collar vote, having hit a low of $27 \%$ in 1998, has climbed; in 2004 it constituted 39\% of the Coalition's vote.

It does not follow, however, that the occupational structuring of the vote is a thing of the past. The Alford (1964) index of 'class voting' may have collapsed in 1996, when the difference between the proportions of manual and non-manual respondents voting Labor (ignoring other parties of the 'left') dropped to as little as 7 percentage points. But even in 1996 there was still a world of difference between the level of support for Labor among public sector employees or unionised industrial labourers, on the one side, and the self-employed on the other. More generally, the net differences in levels of party support (the Coalition compared to Labor), in 1996 compared to 1979 , among government and private employees ( 26 percentage points in 1996; 24 in 1979), union members and non-union members (45 points compared to 31), and the self-employed compared to those not self-employed (55 points compared to 56), was as great as or greater than it was in 1979 (McAllister 1997, 258 for the

\footnotetext{
${ }^{2}$ As the AES, like most surveys, is biased towards the better educated (Goot 2000), what we are emphasising here is the trend in the figures and not the absolute values.
} 
data, not the interpretation). Clive Hamilton's view that 'while four out of five participants in the labour force remain wage and salary earners', affluence means that 'class as a political category has virtually disappeared' (2006, 20-1) is difficult to support.

Contrary to the view that Howard won a new constituency in 1996 and has held on to it, more or less, ever since our analysis highlights the volatile nature of the Coalition's gains. In 1998 the Coalition's vote among blue-collar respondents dropped close to where it had been in 1993 and remained there. Not until 2004 did Howard win most of this constituency back.

But how important has the shift in blue-collar voting been? If we compare the AES data for the pre-Howard elections (1987-93) with those that cover the elections held since, we find no trend in blue-collar support for the Coalition, net of other demographic factors. What our analysis suggests is that the changes in the Coalition's fortunes have more to do with education than with occupation. Howard has built his support not so much among blue-collar workers as among voters with relatively low levels of education. In addition, he has extended the Coalition's advantage among older voters (aged 60 plus years). So the swing to the Coalition may be less the story of a shift in the labour market than a story about populist right-wing politics mediated by talkback radio - a medium that Howard has made his ownand pitched at those with limited education and older voters with a less critical insight into social and political affairs. ${ }^{3}$

What of the change in the 'Catholic vote'? One possibility is a re-run of the old story: Catholic 'aspiration'. But why aspiration should be particularly marked among Catholics is less obvious now than it was in the heyday of the DLP-and even then it was far from clear that aspirations of a material kind were the key to the shift in the Catholic vote (Spann 1961). Another possibility is that the Catholic connection with Labor is partly the product of a church whose teachings on issues like asylum seekers are more liberal than conservative; that church attendance has declined; and that this decline has left increasing numbers of Catholics available to parties of the Right. But since the 1996 data suggest that Catholics who attended church most often were more likely to support the Coalition (Smith 1998, 2001), this seems unlikely. It is more likely that Howard, who prides himself on the number of Catholics in his Cabinet, has shifted these voters by emphasising conservative values that Catholics endorse (Williams 1997, 84, for Howard's analogy with the DLP).

And what of the trade union vote? Of all the demographic variables, trade union membership is possibly the strongest, and certainly most consistent, predictor of the Labor vote. If WorkChoices makes it more difficult for workers to join a trade union, the Coalition will have struck a blow not only against collective action in the workplace but also at Labor's electoral heartland.

One of the things our research helps revive is the notion that issues matter. We have shown that: in 1996, unemployment, privatisation, the environment and defence made a difference; in 1998, unemployment, privatisation, education and interest rates made a difference; in 2001, unemployment, health and Medicare, and 'the war on terror' made a difference; and in 2004, unemployment, interest rates, defence, 'the war on terror' and the Iraq war made a difference. This is a formidable list. That some issues (defence, terrorism and interest rates) have worked in the

\footnotetext{
${ }^{3}$ For the strong relationship between conservative views on law and order, and dependence on commercial radio and television, see Goot and Watson (2007, Table 4).
} 
Coalition's favour whereas others (health, education, privatisation and the environment) have benefited Labor lends weight to scepticism (Goot 2004) about claims that we are living through an era of party 'convergence'.

Judgements that the state of the economy had improved in the past 12 months were invariably more powerful influences on the vote than judgements that household finances had improved in the past 12 months. There is a paradox here as other research, which is based on rates of inflation, unemployment and so on, shows "no support for the hypothesis that economic performance has a direct impact on government popularity' (McAllister 2003b, 259; see also Mughan 1987; Jackman and Marks 1994). However, judgements that household finances had gone backwards in the past 12 months were more powerful in 1998, 2001 and 2004, than judgements that the country had gone backwards in the past 12 months; only in 1993 and 1996 were these relative weights reversed.

Although our conclusion does not necessarily confound the notion that voters are overwhelmingly egocentric (sociotropic judgements may be self-centred), it does confound the notion that it is simply their 'pocketbooks' that govern how people vote.

Finally, we note that in 1996 those respondents who cared 'a good deal' which party won helped bring to an end Labor's 13 years in office and, in 2004, they helped repel Labor's third attempt to win it back. What is interesting here is that the basis for caring which party won apparently lay not in any commitment to the notion that a change of government was a good thing in itself; rather, it seemed to spring from the notion that which of the parties was in office actually mattered. If this is so, it is another blow to the fashionable notion that the parties are becoming increasingly indistinct.

\section{References}

Alford, R.R. 1964. Party and Society: The Anglo-American Democracies. London: John Murray.

Barnett, D. and P. Goward. 1997. John Howard, Prime Minister. Ringwood, Vic.: Viking.

Barns, G. 2003. What's Wrong With The Liberal Party? Cambridge: Cambridge University Press.

Bean, C., D. Gow and I. McAllister. 1999. Australian Election Study, 1998 [computer file]. Canberra: Australian Social Science Data Archive, ANU.

Bean, C., D. Gow and I. McAllister. 2002. Australian Election Study, 2001 [computer file]. Canberra: Australian Social Science Data Archive, ANU.

Bean, C. and I. McAllister. 1997. 'Short-Term Influences on Voting Behaviour in the 1996 Election.' In The Politics of Retribution: The 1996 Federal Election, eds. C. Bean, M. Simms, S. Bennett and J. Warhurst. St. Leonards, NSW: Allen \& Unwin.

Bean, C. and I. McAllister. 2000. 'Voting Behaviour.' In Howard's Agenda: The 1998 Australian Election, eds. M. Simms and J. Warhurst. St Lucia: University of Queensland Press.

Bean, C. and I. McAllister. 2002. 'From Impossibility to Certainty: Explaining the Coalition's Victory in 2001.' In 2001: The Centenary Election, eds J. Warhurst and M. Simms. St Lucia: University of Queensland Press.

Bean, C. and I. McAllister. 2005. 'Voting Behaviour: Not an Election of Interest (Rates).' In Mortgage Nation: The 2004 Australian Election, eds M. Simms and J. Warhurst. Perth: API Network.

Bean, C., I. McAllister, R. Gibson and D. Gow. 2005. Australian Election Study, 2004 [computer file]. Canberra: Australian Social Science Data Archive, ANU.

Black, J. 2006. 'Lies and Statistics.' Australian Financial Review 28-29 January: 63.

Brown, G. and R. Stewart, eds. 1996. The 1996 Federal Election Symposium. Melbourne: Centre for Corporate Public Affairs.

Charnock, D. 1997a. 'Class and Voting in the 1996 Australian Federal Election'. Electoral Studies 16: $281-300$.

Charnock, D. 1997b. 'Spatial Variations, Contextual and Social Structural Influences on Voting for the ALP at the 1996 Federal Election: Conclusions from Multilevel Analyses.' Australian Journal of Political Science 32: 237-54. 
Curtice, J. 2002. 'The State of Election Studies: Mid-life Crisis or New Youth?' Electoral Studies 21: $161-8$.

Goot, M. 1999. 'Public Opinion, Privatisation and the Electoral Politics of Telstra.' Australian Journal of Politics and History 45: 214-38.

Goot, M. 2000. 'More 'Relaxed and Comfortable": Public Opinion on Immigration under Howard.' People and Place 8(3): 46-60.

Goot, M. 2004. 'Party Convergence Reconsidered.' Australian Journal of Political Science 39: 49-73.

Goot, M. and I. Watson. 2001. 'One Nation's Electoral Support: Where Does it Come From, What Makes it Different, and How Does it Fit?' Australian Journal of Politics and History 47: 159-91.

Goot, M. and I. Watson. 2007. 'Are “Aspirationals” Different?' In Australian Social Attitudes: A Second Report, eds D. Denemark et al. Sydney: University of New South Wales Press.

Gow, D. et al. 1990. Australian Election Study, 1990 [computer file]. Canberra: Australian Social Science Data Archive, ANU.

Hamilton, C. 2006. What's Left? The Death of Social Democracy. Quarterly Essay no. 21. Melbourne: Black Inc.

Hamilton, C. and R. Denniss. 2005. Affluenza: When Too Much Is Never Enough. Crows Nest, NSW: Allen \& Unwin.

Harding, A. 2006. 'Tax and Welfare Traps Ahead.' The Australian 30 October: 12.

Jackman, S. 1998. 'Pauline Hanson, the Mainstream, and Political Elites: The Place of Race in Australian Political Ideology.' Australian Journal of Political Science 33: 167-86.

Jackman, S. and G. Marks. 1994. 'Forecasting Australian Elections: 1993, and All That.' Australian Journal of Political Science 29: 277-91.

Jones, R., I. McAllister, D. Denemark and D. Gow. 1993. Australian Election Study, 1993 [computer file]. Canberra: Social Science Data Archive, ANU.

Jones, R., I. McAllister and D. Gow. 1996. Australian Election Study, 1996 [computer file]. Canberra Australian Social Science Data Archive, ANU.

Jupp, J. 2002. 'Ethnicity and Immigration'. In 2001: The Centenary Election, eds. J. Warhurst and M. Simms. St Lucia: University of Queensland Press.

McAllister, I. 1997. 'Political Behaviour.' In Government, Politics, Power and Policy in Australia, 6th edn, eds. D. Woodward, A. Parkin and J. Summers. South Melbourne: Wesley Addison Longman Australia.

McAllister, I. 2003a. 'Border Protection, the 2001 Australian Election and the Coalition Victory.' Australian Journal of Political Science 38: 445-63.

McAllister, I. 2003b. 'Prime Ministers, Opposition Leaders and Government Popularity in Australia.' Australian Journal of Political Science 38: 258-78.

McAllister, I. and C. Bean. 2000. 'The Electoral Politics of Economic Reform in Australia: The 1998 Election.' Australian Journal of Political Science 41: 383-99.

McAllister, I. and C. Bean. 2006. 'Leaders, the Economy or Iraq? Explaining Voting in the 2004 Australian Election.' Australian Journal of Politics and History 52: 604-20.

McAllister, I., R. Jones, E. Papadakis and D. Gow. 1990. Australian Election Study, 1990 [computer file]. Canberra: Social Science Data Archive, ANU.

McAllister, I. and A. Mughan. 1987. Australian Election Study, 1987 [computer file]. Canberra: Social Science Data Archive, ANU.

McCrann, T. 1996. 'Seismic Shift in Voting Against Triangle of Power,' The Weekend Australian 9-10 March: 8.

Megalogenis, G. 2006. The Longest Decade. Melbourne: Scribe.

Mughan, A. 1987. 'The "Hip Pocket Nerve" and Electoral Volatility in Australia and Great Britain.' Politics 22(2): 66-75.

Robb, A. 1996. Address to the National Press Club. URL: <http://www.liberal.org.au > Consulted 12 September 2006.

Robb, A. 1997. 'The Liberal Party Campaign.' In The Politics of Retribution: The 1996 Federal Election, eds C. Bean, M. Simms, S. Bennett and J. Warhurst. St Leonards, NSW: Allen \& Unwin.

Smith, R. 1998. 'Religion and Electoral Behaviour in Australia: Search for Meaning.' Australian Religion Studies Review 11(2): 17-37.

Smith, R. 2001. Australian Political Culture. Frenchs Forest, NSW: Longman.

Spann, R.N. 1961. 'The Catholic Vote in Australia.' In Catholics and the Free Society, ed. H. Mayer. Melbourne: F.W. Cheshire.

Williams, P. 1997. The Victory: The Inside Story of the Takeover of Australia. St Leonards, NSW: Allen \& Unwin. 


\section{Appendix}

Table A1. Multinomial logit results, Australian Election Studies, 1993-2004: Demographic model

\begin{tabular}{|c|c|c|c|c|c|}
\hline & 1993 & 1996 & 1998 & 2001 & 2004 \\
\hline \multicolumn{6}{|l|}{ LNP $v s$ ALP } \\
\hline Male & $0.77^{*}$ & $0.71^{*}$ & $0.69^{*}$ & 1.05 & 1.04 \\
\hline Aged $30-39$ years & $0.71^{* * *}$ & $0.71^{* *}$ & $0.63^{* * *}$ & 0.87 & 1.10 \\
\hline Aged $40-49$ years & 1.05 & 0.91 & 0.96 & 0.85 & 0.84 \\
\hline Aged $50-59$ years & $1.40^{* *}$ & 1.31 & $1.33^{*}$ & 1.16 & 0.88 \\
\hline Aged 60 years and over & 1.06 & 1.26 & $1.65^{* * *}$ & $1.76^{* * *}$ & 1.24 \\
\hline No post-school qualifications & 0.95 & 0.84 & 1.00 & 1.00 & $0.70^{*}$ \\
\hline Trade qualifications & 1.07 & 0.79 & 1.31 & 1.25 & 1.06 \\
\hline University qualifications & 1.02 & 0.78 & 1.40 & $0.62^{*}$ & 0.77 \\
\hline Self-employed & $2.25^{* * *}$ & $3.38^{* * *}$ & $1.58^{* *}$ & 1.38 & $1.96^{* * *}$ \\
\hline Managers & $1.63^{* * *}$ & 1.10 & $1.54^{*}$ & $1.56^{* *}$ & 1.31 \\
\hline Professionals & 1.00 & 0.93 & 1.16 & $1.40^{*}$ & 1.04 \\
\hline Other white collar & 1.08 & 1.03 & 0.88 & 1.07 & 1.10 \\
\hline Blue collar & $0.59^{* * *}$ & 0.88 & $0.63^{* *}$ & $0.54^{* * *}$ & $0.72 *$ \\
\hline Private sector & 1.16 & 1.33 & 1.35 & $1.65^{* *}$ & $1.40^{*}$ \\
\hline Trade union member & $0.58^{* * *}$ & $0.50^{* * *}$ & $0.46^{* * *}$ & $0.60^{* *}$ & $0.46^{* * *}$ \\
\hline Supervisory position & 1.04 & $1.45^{* *}$ & 1.23 & 1.19 & 1.00 \\
\hline Born overseas & 0.95 & 0.85 & 0.85 & $0.60^{*}$ & 0.78 \\
\hline Born overseas in NES country & 0.79 & $0.65^{*}$ & $0.57^{* *}$ & $0.61^{* *}$ & 0.97 \\
\hline Low income & $0.65^{* *}$ & 0.66 & $0.37^{* * *}$ & $0.43^{* * *}$ & $0.63^{*}$ \\
\hline Middle income & $0.72^{*}$ & 0.75 & $0.67^{*}$ & 0.87 & 0.76 \\
\hline Catholic religion & $0.65^{* * *}$ & 0.96 & 0.79 & 0.77 & 1.16 \\
\hline Anglican religion & 1.07 & 1.33 & 0.98 & 1.16 & $1.75^{* * *}$ \\
\hline Married & $1.37^{* *}$ & 1.08 & 1.29 & 1.32 & 1.14 \\
\hline Living in city & $0.81^{*}$ & $0.76^{*}$ & $0.71^{*}$ & 0.85 & $0.70^{* *}$ \\
\hline Constant & 1.49 & 1.71 & 1.75 & 1.03 & 1.52 \\
\hline \multicolumn{6}{|l|}{ Other parties vs $A L P$} \\
\hline Male & 0.90 & 0.69 & 0.77 & 0.92 & 1.02 \\
\hline Aged $30-39$ years & 0.99 & 1.20 & $0.72 *$ & 1.21 & 1.16 \\
\hline Aged $40-49$ years & 1.14 & 0.73 & 1.13 & 0.97 & 1.14 \\
\hline Aged $50-59$ years & 0.87 & 1.20 & $1.52^{*}$ & 1.03 & 0.88 \\
\hline Aged 60 years and over & 0.91 & 0.64 & 0.77 & 1.09 & 1.00 \\
\hline No post-school qualifications & 0.79 & 0.68 & 0.65 & 0.71 & 0.62 \\
\hline Trade qualifications & 1.24 & $0.49^{*}$ & 1.22 & 0.82 & 0.64 \\
\hline University qualifications & 1.39 & 0.69 & 1.19 & 0.90 & 1.54 \\
\hline Self-employed & 0.92 & $2.66^{* * *}$ & 1.15 & 1.52 & 1.26 \\
\hline Managers & 1.52 & 0.68 & 0.92 & 1.17 & 0.93 \\
\hline Professionals & $2.09^{* *}$ & 0.98 & 1.00 & $1.69^{* *}$ & 1.14 \\
\hline Other white collar & 1.49 & 0.80 & 0.82 & 1.01 & 1.03 \\
\hline Blue collar & 0.82 & 1.08 & 0.84 & $0.62^{*}$ & 1.00 \\
\hline Private sector & 1.20 & 0.99 & 0.79 & $1.83^{* *}$ & 1.45 \\
\hline Trade union member & $0.59^{* *}$ & $0.58^{*}$ & $0.56^{* *}$ & 0.90 & 0.70 \\
\hline Supervisory position & $0.68^{*}$ & 1.01 & 1.16 & 0.87 & 0.90 \\
\hline Born overseas & 1.13 & 1.08 & 0.80 & 0.70 & 0.93 \\
\hline Born overseas in NES country & 0.87 & 0.50 & $0.41^{* *}$ & $0.61^{*}$ & 0.67 \\
\hline Low income & $0.46^{*}$ & $0.45^{*}$ & 1.00 & 0.90 & 0.87 \\
\hline Middle income & 0.72 & 0.84 & 1.04 & 1.36 & 0.73 \\
\hline Catholic religion & $0.44^{* * *}$ & $0.58^{*}$ & $0.65^{*}$ & $0.60^{* *}$ & $0.55^{* *}$ \\
\hline Anglican religion & 0.68 & 0.85 & 0.71 & 0.90 & 0.71 \\
\hline
\end{tabular}


Table A1. Continued

\begin{tabular}{lccccc}
\hline & 1993 & 1996 & 1998 & 2001 & 2004 \\
\hline Married & 1.12 & 0.92 & 1.11 & $0.63^{* *}$ & $0.55^{* *}$ \\
Living in city & 1.13 & 1.08 & 0.75 & 0.81 & $0.66^{*}$ \\
Constant & $0.43^{*}$ & 1.12 & 1.30 & 0.67 & 1.14 \\
Statistics & & & & & \\
No. observations & 2330 & 1380 & 1382 & 1481 & 1314 \\
Log-likelihood & -2061.73 & -1255.51 & -1349.32 & -1438.04 & -1233.76 \\
Pseudo $r^{2}$ & 0.09 & 0.09 & 0.08 & 0.07 & 0.07 \\
\hline
\end{tabular}

Notes: Data weighted by Australian Electoral Commission returns.

Coefficients are shown in exponential form; that is, as relative risk ratios (similar to odds ratios).

Omitted dummy categories that were not self-evident (reference groups): age: 18-29 years; occupation: 'other' (i.e. non-working), although the comparison is against the grand mean rather than against the omitted category; employment sector: public; place of birth: Australian-born; income: high income; religion: other, including non-believers.

${ }^{*} p<0.05 ;{ }^{* *} p<0.01 ;{ }^{* * *} p<0.001$.

Table A2. Multinomial logit results, Australian Election Studies, 1993-2004: Full model

\begin{tabular}{|c|c|c|c|c|c|}
\hline & 1993 & 1996 & 1998 & 2001 & 2004 \\
\hline \multicolumn{6}{|l|}{$L N P$ vs $A L P$} \\
\hline Male & 1.00 & 0.76 & $0.64^{* *}$ & 0.99 & 1.16 \\
\hline Aged $30-39$ years & 0.81 & 0.78 & $0.44^{* * *}$ & 0.95 & 0.84 \\
\hline Aged $40-49$ years & 1.16 & 0.72 & 1.02 & 0.90 & 0.75 \\
\hline Aged 50-59 years & 1.25 & $1.56^{*}$ & $1.51^{*}$ & 1.24 & 0.89 \\
\hline Aged 60 years and over & 1.04 & $1.51^{*}$ & $2.72^{* * *}$ & $1.74^{* * *}$ & $1.48^{*}$ \\
\hline No post-school qualifications & 0.98 & 0.80 & 1.01 & 1.08 & $0.55^{*}$ \\
\hline Trade qualifications & 0.89 & 0.60 & 1.25 & 1.16 & 0.79 \\
\hline University qualifications & 1.22 & 0.92 & $1.72 *$ & 0.67 & 0.97 \\
\hline Self-employed & $2.21^{* * *}$ & $3.04^{* * *}$ & $1.60^{*}$ & 1.38 & $2.41^{* * *}$ \\
\hline Managers & $1.73^{* *}$ & 0.82 & 1.49 & 1.34 & 1.41 \\
\hline Professionals & 0.88 & 1.09 & 0.91 & 1.27 & 1.30 \\
\hline Other white collar & 1.20 & 0.91 & 0.83 & 1.24 & 1.15 \\
\hline Blue collar & $0.52^{* * *}$ & 0.99 & 0.80 & $0.65^{*}$ & 0.83 \\
\hline Private sector & 1.22 & 1.29 & 1.13 & 1.29 & 0.99 \\
\hline Trade union member & $0.69^{*}$ & $0.57^{* *}$ & $0.50^{* * *}$ & $0.59^{* *}$ & $0.45^{* * *}$ \\
\hline Supervisory position & 1.15 & $1.55^{*}$ & 1.02 & 1.31 & 0.85 \\
\hline Born overseas & 1.11 & $0.57^{*}$ & 0.87 & $0.56^{*}$ & 0.88 \\
\hline Born overseas in NES country & $0.57^{*}$ & 0.69 & $0.58^{*}$ & $0.59^{*}$ & 0.81 \\
\hline Low income & $0.55^{* *}$ & 0.61 & $0.30^{* * *}$ & 0.61 & 0.86 \\
\hline Middle income & $0.67^{*}$ & 0.82 & $0.61^{*}$ & 1.03 & 0.81 \\
\hline Catholic religion & 0.73 & 0.85 & 0.74 & 0.83 & 1.18 \\
\hline Anglican religion & 1.02 & 1.26 & 1.02 & 1.16 & 1.48 \\
\hline Married & $1.77^{* * *}$ & 1.04 & 1.30 & 1.18 & 0.88 \\
\hline Living in city & 1.01 & 0.77 & $0.65^{* *}$ & 0.81 & $0.65^{*}$ \\
\hline Household finances improved & 1.00 & 0.96 & 1.09 & 0.98 & 1.31 \\
\hline Household finances worsened & $1.47^{*}$ & $1.58^{*}$ & $0.43^{* * *}$ & $0.42^{* * *}$ & $0.60^{*}$ \\
\hline Country economy improved & 1.01 & $0.27^{* * *}$ & $1.88^{* *}$ & $2.61^{* * *}$ & $1.95^{* *}$ \\
\hline Country economy worsened & $2.74^{* * *}$ & $2.87^{* * *}$ & 1.19 & 0.75 & 0.95 \\
\hline Future economy will improve & $0.15^{* * *}$ & $5.71^{* * *}$ & $4.32 * * *$ & $1.61^{*}$ & $2.98^{* * *}$ \\
\hline Future economy will worsen & $4.85^{* * *}$ & $0.15^{* * *}$ & 0.73 & $0.58^{* *}$ & $0.23^{* * *}$ \\
\hline Health issue important & $0.60^{* *}$ & $0.58^{*}$ & 0.86 & 0.69 & $0.43^{* * *}$ \\
\hline Ind. relations issue important & 0.83 & 0.76 & 0.96 & 1.03 & 1.12 \\
\hline Unemployment issue important & $1.60^{* *}$ & $1.93^{* *}$ & $0.50^{* * *}$ & $0.61^{* *}$ & $0.67^{*}$ \\
\hline Education issue important & $0.65^{* *}$ & 0.72 & $0.62^{*}$ & $0.51^{* * *}$ & $0.55^{* *}$ \\
\hline
\end{tabular}


Table A2. Continued

\begin{tabular}{|c|c|c|c|c|c|}
\hline & 1993 & 1996 & 1998 & 2001 & 2004 \\
\hline Environment issue important & $0.53^{* * *}$ & $0.59^{* *}$ & 0.86 & 0.80 & $0.56^{* *}$ \\
\hline Interest rates issue important & 1.01 & 0.81 & $1.71^{* *}$ & & $2.88^{* * *}$ \\
\hline GST issue important & $0.55^{* * *}$ & & 0.71 & $0.30^{* * *}$ & \\
\hline Privatisation issue important & & $0.61^{*}$ & $0.43^{* * *}$ & & \\
\hline Defence issue important & & $2.62^{* * *}$ & & 1.38 & $2.16^{* * *}$ \\
\hline Terrorism & & & & $1.96^{* * *}$ & $2.46^{* * *}$ \\
\hline Tax issue important & & $1.58^{*}$ & $1.91^{* * *}$ & $1.43^{*}$ & 1.20 \\
\hline Immigration issue important & & 1.05 & 0.99 & $1.73^{* *}$ & 1.47 \\
\hline Links with Asia important & & 0.67 & 1.39 & & \\
\hline Refugee issue important & & & & 1.20 & 0.75 \\
\hline Iraq war issue important & & & & & $0.31^{* * *}$ \\
\hline Changed vote from last election & $2.25^{* * *}$ & $3.05^{* * *}$ & 1.23 & 1.39 & 1.07 \\
\hline Cared who won election & & $2.73^{* * *}$ & 1.06 & $1.65^{* *}$ & $2.56^{* * *}$ \\
\hline Keating perceived as arrogant & & 1.33 & & & \\
\hline Constant & 1.27 & 0.54 & $3.24^{* *}$ & 1.56 & 1.41 \\
\hline \multicolumn{6}{|l|}{ Other parties vs ALP } \\
\hline Male & 1.29 & 0.72 & $0.59^{*}$ & 0.91 & 1.02 \\
\hline Aged $30-39$ years & 0.99 & 1.28 & $0.60^{* *}$ & 1.24 & 1.08 \\
\hline Aged $40-49$ years & 1.32 & 0.72 & 1.23 & 0.97 & 1.17 \\
\hline Aged $50-59$ years & 0.75 & 1.39 & $1.53^{*}$ & 1.25 & 1.02 \\
\hline Aged 60 years and over & 1.29 & 0.71 & 1.37 & 1.11 & 1.25 \\
\hline No post-school qualifications & 0.85 & 0.77 & $0.58 *$ & 0.75 & 0.59 \\
\hline Trade qualifications & 1.00 & $0.44^{*}$ & 0.99 & 0.70 & 0.61 \\
\hline University qualifications & 1.34 & 0.79 & 1.51 & 0.84 & 1.46 \\
\hline Self-employed & 0.76 & $2.99^{* * *}$ & 0.86 & 1.52 & 1.22 \\
\hline Managers & 1.72 & 0.83 & 0.92 & 1.29 & 0.86 \\
\hline Professionals & 1.61 & 1.16 & 0.70 & $1.62^{*}$ & 1.10 \\
\hline Other white collar & 1.59 & 0.84 & $0.65^{*}$ & 0.98 & 0.91 \\
\hline Blue collar & 0.70 & 1.14 & 0.95 & $0.58^{*}$ & 1.11 \\
\hline Private sector & 1.59 & 0.79 & 0.73 & 1.52 & 1.32 \\
\hline Trade union member & 0.86 & $0.50^{*}$ & $0.54^{* *}$ & 0.89 & 0.71 \\
\hline Supervisory position & 0.75 & 1.03 & 1.31 & 0.82 & 0.83 \\
\hline Born overseas & 1.08 & 0.73 & 0.70 & 0.65 & 0.94 \\
\hline Born overseas in NES country & 0.64 & $0.40^{*}$ & $0.32 * * *$ & 0.76 & 0.61 \\
\hline Low income & $0.43^{*}$ & $0.30^{*}$ & 0.64 & 1.00 & 0.97 \\
\hline Middle income & 0.71 & 0.71 & 0.88 & 1.53 & 0.79 \\
\hline Catholic religion & $0.53^{*}$ & $0.54^{*}$ & 0.76 & 0.86 & 0.61 \\
\hline Anglican religion & 0.73 & 0.85 & 0.83 & 1.23 & 0.66 \\
\hline Married & 1.61 & 1.20 & 0.98 & 0.74 & $0.52^{* *}$ \\
\hline Living in city & 1.46 & 1.25 & 0.86 & $0.68^{*}$ & 0.72 \\
\hline Household finances improved & 0.70 & 1.01 & 1.02 & 0.75 & 1.37 \\
\hline Household finances worsened & 1.03 & 1.15 & 1.36 & 0.95 & 0.73 \\
\hline Country economy improved & 1.52 & 0.56 & 1.53 & 1.18 & 0.89 \\
\hline Country economy worsened & $2.45^{* * *}$ & $3.10^{* * *}$ & 1.29 & $1.94^{* *}$ & 1.11 \\
\hline Future economy will improve & $0.32^{* * *}$ & $2.92^{* * *}$ & $2.12^{*}$ & 1.19 & 1.48 \\
\hline Future economy will worsen & $4.11^{* * *}$ & 0.77 & 0.91 & 0.70 & 0.67 \\
\hline Health issue important & 0.92 & 0.66 & $0.60^{*}$ & 0.76 & $0.39^{* *}$ \\
\hline Ind. relations issue important & 0.85 & 0.59 & 0.85 & 0.90 & 0.75 \\
\hline Unemployment issue important & 1.26 & $1.82^{*}$ & 0.83 & 0.71 & 0.78 \\
\hline Education issue important & $0.60^{*}$ & 0.92 & 0.69 & $0.51^{* *}$ & 1.25 \\
\hline Environment issue important & $2.07^{* *}$ & $2.43^{* *}$ & 1.43 & $2.54^{* * *}$ & 1.62 \\
\hline Interest rates issue important & 0.76 & $0.46^{*}$ & 0.96 & & 1.43 \\
\hline GST issue important & $0.61^{*}$ & & 0.69 & $0.48^{* * *}$ & \\
\hline Privatisation issue important & & 0.89 & 0.72 & & \\
\hline Defence issue important & & $2.19^{*}$ & & 1.10 & 0.95 \\
\hline Terrorism & & & & 0.75 & 1.74 \\
\hline Tax issue important & & 0.87 & 1.54 & 0.72 & 0.80 \\
\hline Immigration issue important & & 1.13 & $2.03^{* *}$ & 1.45 & 0.76 \\
\hline Links with Asia important & & 0.85 & 0.68 & & \\
\hline
\end{tabular}


Table A2. Continued

\begin{tabular}{|c|c|c|c|c|c|}
\hline & 1993 & 1996 & 1998 & 2001 & 2004 \\
\hline Refugee issue important & & & & 1.57 & 1.15 \\
\hline Iraq war issue important & & & & & 0.69 \\
\hline Changed vote from last election & $16.15^{* * *}$ & $10.77^{* * *}$ & $14.74^{* * *}$ & $9.96^{* * *}$ & $5.04^{* * *}$ \\
\hline Cared who won election & & 0.66 & $0.53^{* *}$ & 0.74 & 1.01 \\
\hline Keating perceived as arrogant & & & 1.30 & & \\
\hline Constant & $0.07^{* * *}$ & 0.38 & 0.86 & 0.41 & 1.00 \\
\hline \multicolumn{6}{|l|}{ Statistics } \\
\hline No. observations & 2,232 & 1,297 & 1,309 & 1,416 & 1,255 \\
\hline Log-likelihood & -1315.39 & -808.13 & -964.57 & -996.42 & -858.68 \\
\hline Pseudo $r^{2}$ & 0.39 & 0.38 & 0.30 & 0.33 & 0.33 \\
\hline
\end{tabular}

Notes: Data weighted by Australian Electoral Commission returns.

Coefficients are shown in exponential form; that is, as relative risk ratios (similar to odds ratios).

Omitted dummy categories that were not self-evident (reference groups): age: 18-29 years; occupation: 'other' (i.e. non-working), although the comparison is against the grand mean rather than against the omitted category; employment sector: public; place of birth: Australian-born; income: high income; religion: other, including non-believers; household finances: stayed the same; country economy: stayed the same; future economy: will stay the same.

${ }^{*} p<0.05 ;{ }^{* *} p<0.01 ;{ }^{* * *} p<0.001$. 